\title{
KÖNYV A TANÁRI MESTERSÉG TANULÁSÁHOZ
}

\author{
FÜZI BEATRIX \\ az Óbudai Egyetem Trefort Ágoston Mérnökpedagógiai Központjának \\ tanársegédje \\ fuzi.beatrix@tmpk.uni-obuda.hu
}

A tanárjelöltek első benyomásai, melyeket a tanárképzésben szereznek, a tanári mesterséggel kapcsolatos meghatározó élménnyé válhatnak. Ennek az élménynek része e célcsoport sajátosságait figyelembe vevő szakirodalom is. Szabó László Tamás Bevezetés a tanári mesterségbe címü (tan)könyvével arra vállalkozik, hogy a tanárjelöltek szemléletének megalapozásához nyújtson segítséget.

E szándék megvalósítását szolgálja a könyv felépítésével és logikájával is, így például a csomóponti témák többszöri érintésével, a fejezetek végén található öszszefoglalással, az ajánlott irodalmak témákhoz rendezett listájával, a szövegbe ágyazott szómagyarázatokkal és egy szaknyelvi kisszótárral.

Lépésről lépésre, fokozatosan vezeti be az olvasót az oktatásügy, az iskola és az osztályterem világába, végül a tanár és diák személyes találkozásakor megtapasztalható problémákba.

Vállalt céljai között szerepel az is, hogy az elmélet és a gyakorlat kapcsolatát minél élőbben mutassa be. Ezért a témák megválasztását mindvégig jellemzi a gyakorlatiasság, a tanári tevékenységben való alkalmazhatóság szempontjának érvényesítése, ugyanakkor megmutatja a szerző véleményformálásának indokait, gondolkodásának filozófiai hátterét és mélységeit. Ennek eredményeképpen üdítően kapcsolódnak benne a nevelés történetéből kiragadott részek és az aktualitás, melynek elözményei és kibontakozása is világossá válik. Továbbá ezért férhetnek meg jól egymással és alkothatnak szerves egységet többek közt a tananyag kiválasztásával, a nevelési eszményekkel kapcsolatos és a digitális bennszülöttségéröl szóló gondolatok.

A szerző munkáira - s köztük az itt bemutatottra is - jellemzö, hogy lényegesnek, kritikusnak tartott kérdésekkel kapcsolatban vállalja az állásfoglalást. Egy tanárjelölteknek szánt tankönyvben ez különösen fontos, hiszen érvelése, véleményalkotási folyamatának feltárása révén mintát adhat arra, hogyan érdemes szakmai kérdéseket mérlegre tenni, megengedve, hogy ennek alapján a hallgatók, az olvasók más következtetésre juthassanak.

A könyv is bizonyítja, hogy az új ismeretek hatékony elsajátítását lényegesen segítheti az érzelmek bevonása. A szerző mondanivalóját alátámasztó, szemléltető példák - dalszövegek, meglepő osztálytermi párbeszédek, dolgozatrészletek - elö- 
hívják az olvasó saját emlékeit, élményeit, összekötve ezzel a személyes tapasztalatokat a tanári mesterséghez kapcsolódó tudáselemekkel.

$\mathrm{S}$ hogy melyek azok a tudnivalók, témák, melyek átgondolását fontosnak tartja a tanárképzést megkezdő hallgatók számára?

Az első rész többek közt az iskolarendszerről, az oktatás tervezésének szintjeiről és dokumentumairól, a tananyag kiválasztásáról, a nevelés és az oktatás megbonthatatlan egységéről, a célok oktatástervezésben, továbbá az értékek iskolában betöltött szerepéről szól.

A második fejezet az iskolai munka eredményességét alapvetően befolyásoló tényezőket veszi számba, így például a növendékek és a tanár viszonyát, a tanulás, a tudás konstruálás sajátosságait, és ezek érzelmekkel való kapcsolatát, a tanítás kommunikáció elméleti vetületét, a tanári döntések szerepét, a rejtett tantervet és a reflektív tanári attitüdöt.

A harmadik részben a szerző arra a kérdésre keresi a választ, hogy mi az iskola feladata, szerepköre a mediatizált, felgyorsult világban, mely a villámgyorsan megszerezhető és azonnal alkalmazható tudást részesíti előnyben.

A könyv lényeges üzenete, hogy az értékrend kimüvelése, megszilárdítása kulcsfontosságú a tanárképzés kezdeti szakaszában. Hiszen ahhoz, hogy a diákok egyre sokszínübb közösségeiben a tanári tevékenység eredményes legyen, a saját értékekben és értékrendben való magabiztos eligazodásra van szükség.

Arra ösztönzi a tanár szakos hallgatókat, hogy alakítsák ki saját tanári filozófiájukat, és ehhez ajánlja a növendékek támogatásának és megértésének igényét, továbbá az önfejlesztés és a reflektivitás igényét.

Azzal, hogy a könyvben a pedagógia egyes területei nem elkülönülten, hanem kérdések köré szerveződve, komplex módon jelennek meg, segítik a tanári tevékenységet átfogó, koherens, az összefüggéseket értő szemlélet megalapozáát. A problémák ilyen komplex látása, átlátása, a szerző sok éves tapasztalatának gyümölcse. Komoly feladat lépést tartani vele ezen a gondolati úton, ugyanakkor az olvasó kiérlelt útmutatást, magyarázatokat kaphat a felmerülő kérdésekre.

A tanárjelölteken kívül a pedagógiában járatos, tudását frissíteni, rendszerezni kívánó olvasó számára is hasznos olvasmány lehet ez a könyv. Ráadásul ritka az olyan szakirodalom, mely az értékes gondolatok mellett - példáinak köszönhetöen - szórakoztató is.

Szabó László Tamás (2010): Bevezetés a tanári mesterségbe. Debreceni Egyetemi Kiadó, Debrecen, 148 oldal 